\title{
Ecosystem processes, management and human dimension of tectonically-influenced wetlands along the coast of central and southern Chile
}

\section{Procesos ecosistémicos, manejo y dimensiones humanas en humedales costeros influenciados por tectónica en el sur de Chile}

\author{
Nelson A. Lagos $^{1 *}$, Fabio A. Labra ${ }^{1,2}$, Eduardo Jaramillo ${ }^{3}$, Andrés Marín $^{4}$, José Miguel Fariña ${ }^{5}$ \& \\ ANDRÉS CAMAÑO ${ }^{6}$ \\ ${ }^{1}$ Centro de Investigación e Innovación para el Cambio Climático, Facultad de Ciencias, Universidad Santo Tomás, Santiago, \\ Chile. \\ ${ }^{2}$ Doctorado en Conservación y Gestión de la Biodiversidad, Facultad de Ciencias Universidad Santo Tomás, Santiago, Chile. \\ ${ }^{3}$ Instituto de Ciencias de la Tierra, Facultad de Ciencias, Universidad Austral de Chile, Valdivia, Chile. \\ ${ }^{4}$ Centro de Estudios del Desarrollo Regional y Políticas Públicas, Universidad de Los Lagos, Osorno, Chile. \\ ${ }^{5}$ Departamento de Ecología, Facultad de Ciencias Biológicas, Pontificia Universidad Católica de Chile, Santiago, Chile. \\ ${ }^{6}$ SISEC Spa, Avenida Kennedy 6969, Las Condes, Santiago, Chile. \\ *nlagoss@santotomas.cl
}

\begin{abstract}
A Workshop on Coastal Wetlands of Chile was held at Universidad Austral de Chile (Valdivia. november 2017). It was discussed the impact of earthquakes and tsunamis along this coast and their implication for wetlands. These events produce major modifications associated with variable rates of resilience. Emphasis was placed on social dimensions of such disturbances considering their impact on ecosystem services. Societal resilience must be included within the scales of wetland recovery, and incorporated in conservation and management strategies.
\end{abstract}

\section{RESUMEN}

Se realizó en la Universidad Austral de Chile (Valdivia) un Taller sobre Humedales Costeros del Centro Sur de Chile (noviembre 2017). Se discutió el impacto de terremotos y tsunamis y como estos modifican esos humedales que muestran tasas variables de resiliencia. También hubo énfasis en las dimensiones sociales de esas perturbaciones, incluyendo cambios en los servicios ecosistémicos. La resiliencia social debe reconciliarse con las escalas de resiliencia de los humedales, para ser incorporada en estrategias de conservación y manejo.

Chile has nearly $1.3 \times 10^{6}$ hectares of wetlands; only 13 of them have been assigned the status of Ramsar sites accounting for an area close to 361.000 hectares. Nine of those sites are under the administration of the forestry governmental agency CONAF (“Corporación Nacional Forestal"; http:// www.conaf.cl), while private companies administer another three, whereas one is under the administration of the Ministry of the Environment of Chile. The Río Cruces wetland is located northwest of the city of Valdivia (Fig. 1) and it was nominated as the first Ramsar site in Chile in July 1981. The origin of the wetland dates back to May 1960, when a $M_{w} 9.5$ earthquake hit southern Chile affecting large coastal zones by coseismic land subsidence (Plafker \& Savage, 1970; Cisternas et al. 2005). Shallow areas of approximately 4.000 ha were flooded and mostly occupied by swamps and marsh vegetation. Almost 20 years later, the
Río Cruces wetland had become an area with high diversity of aquatic birds and macrophytes and the main reproductive site in the Neotropical region of the iconic Black-necked swan Cygnus melancoryphus (Schlatter 1998).

Research and development of conservation and monitoring strategies in the Rio Cruces wetland were strongly powered in 2004, when an environmental disaster threatened the conditions of the ecosystem. The conservation status of Black-necked swans was seriously endangered, when notorious environmental changes in the wetland were accompanied by emigration and mortality of swans and declining cover of the aquatic macrophyte plant Egeria densa, that used to be the primary food item of herbivorous water birds such as swans (Corti \& Schlatter, 2002; Norambuena \& Bozinovic, 2009; Lagos et al. 2008). Those environmental changes were recognized as a direct 
consequence from a pulse disturbance event caused by the initial industrial operations of a pulp mill plant located upstream from the Río Cruces wetland (Escaida et al. 2015; UACh 2015). The recovery processes begun in 2012 (Jaramillo et al. 2018a, 2018b) and today, nearly 14 years after the disturbance, the population abundances and health conditions of swans, the spatial cover of the aquatic plant E. densa, and the transparency of waters across the wetland have recovered to their initial undisturbed state. The abundance of the affected biotic components of the wetland appear to be healthy (UACh, 2015, 2017) and include biotic components such as macrophytes, fishes, and river shrimps, amongst others (Lagos et al. 2008).

The evaluation and ongoing monitoring programs of the Río Cruces wetland based on an industry-academy agreement, fostered a renewed interest to integrate approaches and gather knowledge about temperate wetland ecosystems in the region. This process is driven by the urgent need to generate management, conservation, and restoration strategies for wetlands under growing human and climatic pressures, and led to the organization of the first Workshop on Coastal Wetlands of Central and Southern Chile held at Universidad Austral de Chile in Valdivia during late spring of 2017. The workshop brought a diverse group of keynote speakers, including environmental and social scientists from Chilean Universities, policy-makers, and private sector representatives, providing the first opportunity to describe the current health conditions of the Río Cruces wetland. This forum was complemented by a synthesis of our understanding of the structure and function of coastal wetlands in the Chilean temperate region, and a discussion about governance needs, community engagement, and opportunities to strengthen the resilience and sustainability of these aquatic ecosystems. The present note summarizes the main conclusions of the Valdivia workshop, and highlights how the uniqueness of the coastal wetlands of central and southern Chile - particularly determined by their location along the most active tectonic coast in the world - impinge on management and conservation strategies for these valuable ecosystems.

The structure and function of coastal wetlands along the Chilean temperate region evidence the role of multiple global, regional and local stressors interacting with sudden large natural disturbances such as earthquakes, tsunamis, and storms (González et al. 2017; Valdovinos et al. 2017). Coastal ecologists and natural resource managers are taking notice of the important role of those events on wetland dynamics, an issue broadly discussed among the attendants to the workshop. Studies carried out by Dr. Manuel ContrerasLopez and colleagues (Universidad de Playa Ancha, Valparaíso) in central Chile (ca. $33^{\circ} \mathrm{S}$ ), demonstrate $0.5^{\circ} \mathrm{C}$ increase in terrestrial temperatures during the last 50 years, $10 \%$ reduction of rainfall, and a sea level rise of $3.3 \mathrm{~mm}$ year ${ }^{-1}$, which is concomitant with the increased occurrence of extreme climatic events such as storm surges affecting the geomorphology and wetlands along the coast (ContrerasLópez et al. 2016; Martínez et al. 2017; Carvajal et al. 2017). Furthermore, the importance of tidal variability in coastal wetlands was emphasized in the workshop by Dr. Mario Pino (Universidad Austral de Chile). Associated studies from this research group along the Río Cruces wetland (UACh 2015) addressed the re-suspension of iron-enriched sediments causing deterioration of sanitary conditions in aquatic macrophytes during the pulse disturbance event of 2004 and subsequent cascading effects on population abundances, body weights and liver conditions of Black-necked swans (Jaramillo et al. 2018a, 2018b).

On the other hand, the recent occurrence of major earthquakes $\left(\mathrm{M}_{\mathrm{w}}>8\right)$ in Chile $(2010,2015)$ evidenced the crucial impact of tsunamis on the structure and function of coastal wetlands. For example, the wetland along the river mouth of Río Mataquito $\left(35^{\circ} \mathrm{S}\right.$; Fig. 1) is located along the rupture zone of the 2010 Maule earthquake, was strongly affected by co-seismic land subsidence and tsunami (Valdovinos et al. 2012, Fariña \& Camaño, 2012). As a consequence, a pre-event $8 \mathrm{~km}$-long sand spit that promoted a broad connection between the estuary mouth and the near ocean waters disappeared (González et al. 2017). A monitoring program led by Dr. Dagoberto Arcos (Universidad Católica de la Santísima Concepción, Concepción) aimed to identify the main processes driving the eventual recovery of the sand spit, as well as the associated physicochemical and biological patterns. The results indicate that the river mouth of the Río Mataquito wetland is quite resilient to this type of natural disturbances, and the sand spit seems to have recovered only 4 months after the tsunami back to the status preceding the earthquake (González et al. 2017).

The spatial distribution of plant communities in coastal wetland ecosystem of central-southern Chile (32-40 ${ }^{\circ} \mathrm{S}$; Fig. 1) reflects the geographic variability of the region, from rather arid conditions in the north to the temperate climate in the south. The zonation pattern of these plants is most evident in the northernmost area; however, climate conditions do not fully explain the observed distribution of plants, suggesting a competitive behavior controlled by additional factors such as the salinity of the soil (Fariña et al. 2018). A previous experimental evaluation of this hypothesis at El Yali wetland failed due to the sudden occurrence of the 2015 tsunami (Fariña et al. 2016). The idiosyncratic impact of seismic events and ensuing tsunamis, may play an important role in resetting the wetland dynamics, by altering the ecological and environmental process across several temporal and spatial scales. However, these severe events seem to exert rather short-lasting effects on coastal wetland ecosystems therefore highlighting their high level of resilience. This assertion might assign a crucial role of frequent earthquakes for the structure and function of coastal wetlands located along the megathrust zone of Chile (Fig.1). 


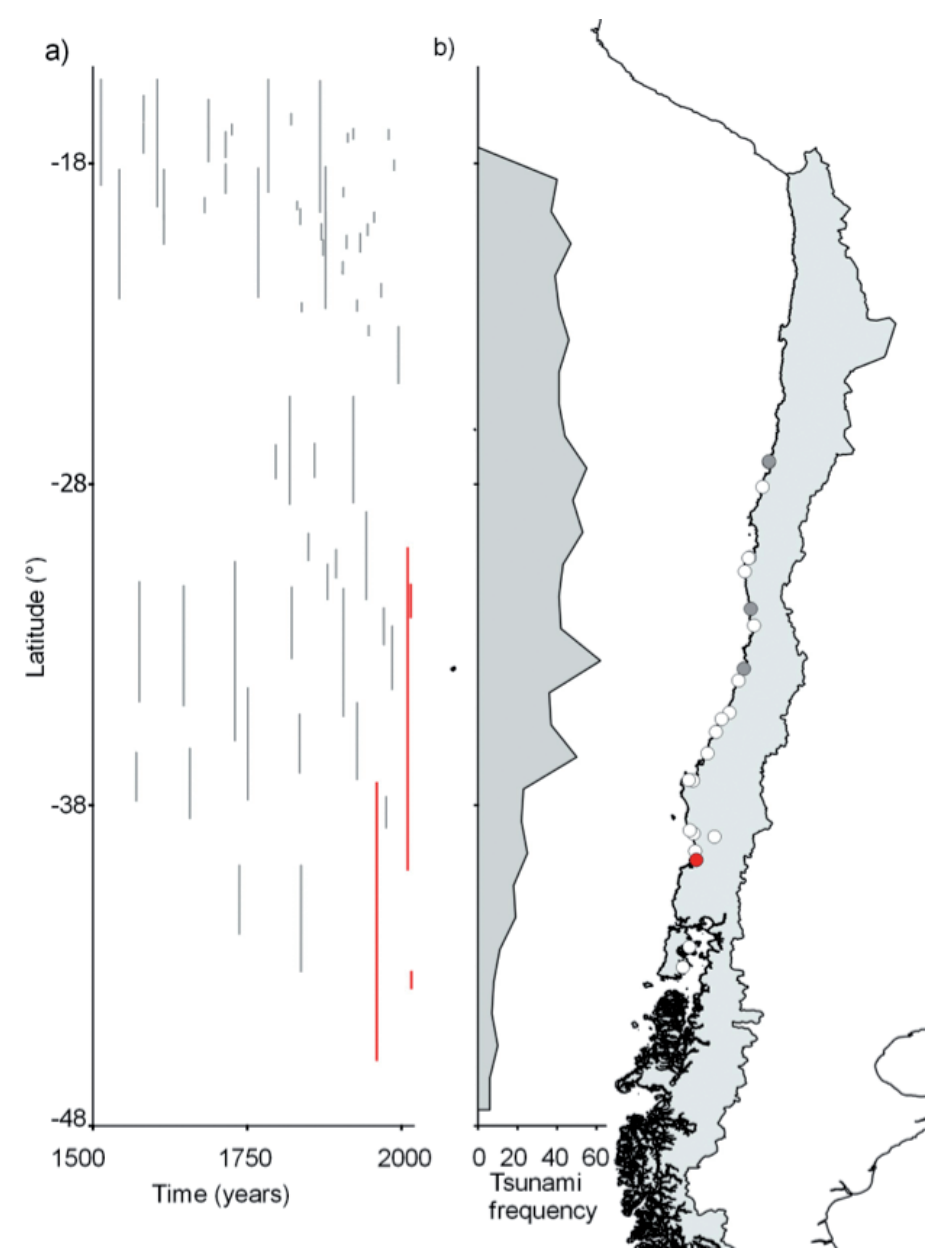

FIgURE 1. Tectonic features along the Chilean coastline. a) Space-time diagram of main earthquakes spanning from year 1500 to the present. Solid vertical lines represent estimated rupture lengths of those earthquakes. Data include uncertain rupture length estimates for historical earthquakes such as those reported in 1575 and 1647. Red lines highlight the strongest seismic events of 1960 (Valdivia), 2010 (Concepción), 2015 (Illapel) and 2016 (Chiloe). Earthquake space time diagram data were obtained by reviewing published information (Comte et al. 1986; Comte \& Pardo 1991; Madariaga 1998; Barrientos 2010; Ruiz et al. 2017). For each seismic event, the year and latitudinal extent of seismic fracture was represented in a spatiotemporal diagram. b) Total number of recorded tsunamis along the coast of Chile between 1562 and 2017. Frequencies were calculated using 1-degree latitudinal bands. The frequency distribution of tsunamis was calculated using data from the NGDC/WDS Global Historical Tsunami Database (NGDC/WDS 2018). We obtained information about 1370 reported tsunami events along the Chilean coast between the years 1562 and 2017. Questionable or doubtful tsunami run-up events were discarded, which provided us with 1299 tsunami run-up events. These were used to estimate the latitudinal extents of each tsunami, assuming continuous impact along the coastline from the northern to the southernmost latitudes reported. Total number of tsunami events were then tallied for 1-degree latitudinal bands spanning from $18^{\circ} \mathrm{S}$ and $48^{\circ} \mathrm{S}$. The open circles marked along the Chilean coast show the spatial location of coastal wetlands mentioned during the workshop. The filled circles refer to Ramsar sites, while the filled red circle highlights the location of the Ramsar site at the Río Cruces wetland. / Características tectónicas a lo largo de la costa chilena. a) Diagrama espacio-tiempo de los principales terremotos ocurridos entre el año 1500 al presente. Las líneas verticales sólidas representan las longitudes estimadas de las zonas de fractura de tales terremotos. Los datos incluyen estimaciones inciertas de longitudes de fractura para terremotos históricos como los de 1575 y 1647. Las líneas rojas resaltan los eventos sísmicos más fuertes: 1960 (Valdivia), 2010 (Concepción), 2015 (Illapel) y 2016 (Chiloé). Los datos para los diagramas espacio-tiempo de los terremotos se obtuvieron de revisiones bibliográficas (Comte et al. 1986; Comte \& Pardo 1991; Madariaga 1998; Barrientos 2010; Ruiz et al. 2017). Para cada evento sísmico, se representa el año y extensión latitudinal de la zona de fractura mediante un diagrama espacio-tiempo. b) Número total de tsunamis registrados a lo largo de la costa chilena entre 1562 y 2017. Sus frecuencias se calcularon usando bandas latitudinales de 1 grado. La distribución de frecuencias de tsunamis se calculó usando datos de NGDC/WDS Global Historical Tsunami Database (NGDC/WDS 2018). Se obtuvo información sobre 1370 tsunamis que ocurrieron en la costa de Chile entre los años 1562 y 2017. No se utilizaron datos dudosos de tsunamis o eventos de "run-up" o salidas de mar lo que entregó un total de 1299 eventos. Estos datos se utilizaron para estimar la extensión latitudinal de cada tsunami, asumiendo un impacto continuo a lo largo de la costa extendida entre los límites norte y sur de las latitudes reportadas. Se estimó entonces el número total de tsunamis para bandas latitudinales de 1 grado entre $18^{\circ} \mathrm{S} \mathrm{y} 48^{\circ} \mathrm{S}$. Los círculos blancos indicados a lo largo de la costa de Chile muestran la localización espacial de humedales costeros mencionados en el workshop. Los círculos negros se refieren a sitios Ramsar, a la vez que los negros muestran la localización del sitio Ramsar humedal del río Cruces. 
During the workshop, Alejandra Figueroa, representative of the Chilean Ministry of the Environment, highlighted that urbanization, industry and climate change, are the major threats to wetlands along the Chilean coast. Some of these wetlands are already in the focus of conservation strategies including the design of restoration plans for sustainability of ecosystem resources. Even though the value of wetlands as natural ecosystems has found recognition in various policies, there is still a lack of specific implications for the zonation of urban vs. natural environments, which is necessary for the conservation of those ecosystems. The management of wetlands requires a proper binding normative implying clear spatial requirement. It certainly needs to consider the needs of the local communities in the decision-making processes, which are usually one of the most vulnerable components of wetland social-ecological systems.

This assertion is illustrated by the study case of the Tubul and Raqui wetland $\left(37^{\circ} \mathrm{S}\right.$; Fig. 1$)$, which was heavily affected by the 2010 Maule earthquake and associated co-seismic uplift $(\sim 1.6 \mathrm{~m})$. This seismic event altered the hydrological regime by drying the tidal channels, desiccation of marsh plants, and disappearance of reintroduced stands of "Pelillo" (Gracilaria sp.), a seaweed of economic importance for local people. The response and adaptation strategies pushed forward by wetland users were quite diverse. Nevertheless, the prevailing trend was to intensify the exploitation of non-impacted ecosystem services (e.g., near-shore benthic resources and inland farmland) that are expected to expose the sustainability of the wetland at even greater risks. A socio-ecological study performed by Dr. Andrés Marín (Universidad de Los Lagos, Osorno) indicates that there are variable perceptions among users about desired future scenarios for the wetland, but they share a common interest regarding the conservation of key ecosystem resources (e.g., freshwater goods and avifauna). The study of the ecological perception among communities around the Rio Cruces wetland reached similar conclusions. In that case, the relationship between the local communities and the wetland, as well as the overall level of trust among relevant actors, were severely eroded after the anthropogenic impacts observed during 2004 (UACh, 2015). These results, and the underlying involvement of local communities, are critical sources of information in the decision-making process and planning for the conservation and sustainability of coastal wetlands (Marín et al. 2014).

The research on wetland ecology has significantly contributed to the understanding of the structure and function of these ecosystems and relevant advances in conservation and management strategies have already been made at global, regional, and local scales. Many of the relevant environmental factors discussed in this first Workshop on Coastal Wetlands of Central and Southern Chile are related to common characteristics of coastal temperate wetlands and thus, provide a basis for synthesis and identification of general usage and conservation strategies. On the other hand, the processes maintaining the structure and function of coastal wetlands periodically exposed to sudden modifications of the physical and biological systems as a consequence of large earthquakes and tsunamis, may well be quite different from those operating in wetlands away from such phenomena. Integrative studies spanning the spatial and temporal scales of those sudden geological processes, represent a major challenge due to the intermittent and stochastic nature of earthquake dynamics. This challenge

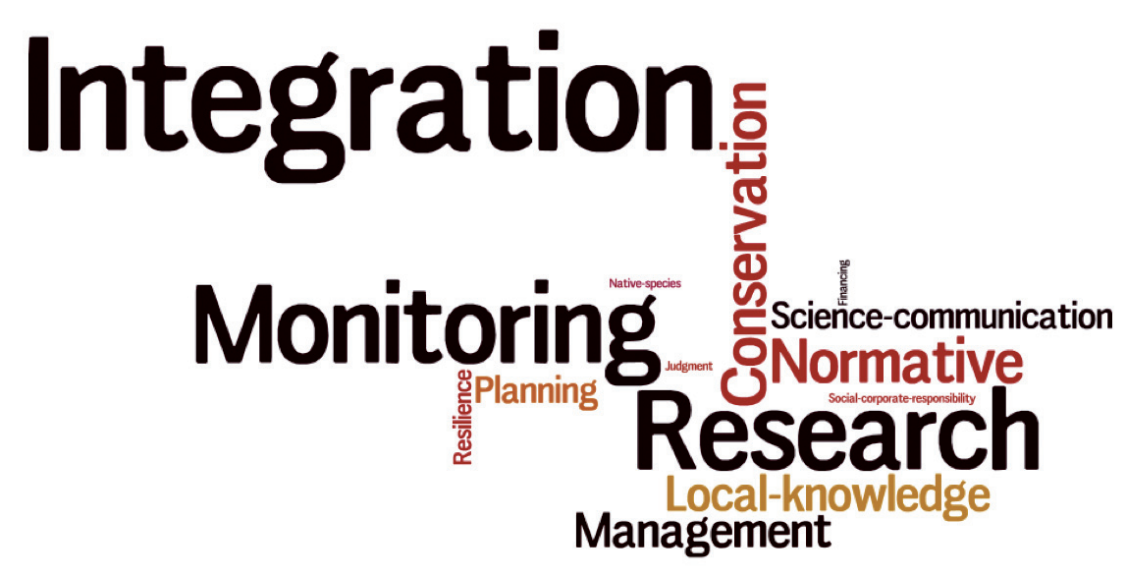

Figure 2. Word cloud generated on the keywords provided by the 26 workshop attendants to the following question: "in relation to the Chilean coastal wetlands: what are the three most relevant needs about biotic, abiotic and socio-ecological issues?"; each of the attendants could provide a maximum of three concepts. The sizes of the words are proportional to the number of mentions for each concept. / Nube de palabras generada con palabras clave entregadas por 26 participantes del workshop ante la pregunta siguiente: en relación a los humedales costeros de Chile: ¿Cuáles son las tres necesidades más relevantes en cuanto a tópicos bióticos, abióticos y socio-ecológicos ?; cada uno de los participantes podía entregar un máximo de tres conceptos. Los tamaños de las palabras son proporcionales al número de menciones para cada concepto. 
includes the combination of different approaches for wetland management and conservation implying transdisciplinarily integration of methods. Furthermore, adaptive management strategies should also take into consideration different climate change scenarios and their impact on the hydric regime of the wetlands.

The integrative character of future strategies was overall considered relevant by the workshop attendants when asked about their perceptions on important needs and challenges in order to improve understanding of the structure and function of Chilean coastal wetlands (Fig. 2). Furthermore, large earthquakes and tsunamis have the potential to alter the conditions and associated resources of wetland ecosystems, and impact the well-being of local communities. Therefore, societal resilience should also be considered within the scales of wetland recovery. Finally, as highlighted by Dr. Andrés Marín, the increased frequency and severity of large natural disturbances along the tectonically active Chilean coast accentuate more than ever the need for intensive trans-disciplinary research including greater engagement with wetland users and their knowledge (Marín et al. 2014), in order to develop policies and strategies for improved management, conservation and sustainability of ecosystem resources in coastal wetlands in Chile and elsewhere.

\section{ACKNOWLEDGMENTS}

We thank Pamela López for editing text and references. We would like to thank Compañia Minera Doña Ines de Collahuasi for financial contribution for the workshop organization and logistic. The writing of this manuscript was facilitated by the Monitoring Program of the Río Cruces wetland. During the writing of this report AM and NAL received funds from the Center for the Study of Multiple-Drivers on Marine Socio-Ecological Systems funded by MINECON Chile NC120086 and CONICYT PIA ANILLOS ACT172037

\section{REFERENCES}

Barrientos, S.E. 2010. Terremoto $(\mathrm{M}=8.8)$ del 27de febrero de 2010 en Chile. Revista de la Asociación Geológica Argentina 67(3):412-420.

Carvajal, M., Contreras-López, M., Winckler, P., Sepúlveda, I. .2017 Meteotsunamis occurring along the southwest coast of south America during an intense storm. Pure and Applied Geophysics 174:3313-3323.

Comte, D., Pardo, M. 1991. Reappraisal of great historical earthquakes in the northern Chile and southern Peru seismic gaps. Natural Hazards 4(1):23-44.

Comte, D., Eisenberg, A., Lorca, E., Pardo, M., Ponce, L., Saragoni, R., SuÁrez, G. 1986. The 1985 central Chile earthquake: a repeat of previous great earthquakes in the region? Science 233(4762):449-453.

Contreras-López, M., Winckler, P., Sepúlveda, I., AndaurÁlvarez, A., Cortés-Molina, F., Guerrero, C.J., Mizobe C.E., Igualt, F., Breuer, W., Beyá, J.F., Vergara, H., Figueroa-Sterquel., R. 2016. Field Survey of the 2015 Chile Tsunami with emphasis on Coastal Wetland and Conservation Areas. Pure and Applied Geophysics 173(2):349-367.

Cisternas, M., Atwater, B.F., Torrejón, F., Sawai, Y., Machuca, G., Lagos, M., Eipert, A., Youlton, C., Salgado, I., Kamataki, T., Shishikura, M., Rajendran, C.P., Malik, J.K., Rizal, Y., Husni, M. 2005. Predecessors of the giant 1960 Chile earthquake. Nature 437(7057): 404-407.

Corti, P., Schlatter, R. 2002. Feeding ecology of the Black necked swan Cygnus melancoryphus in two wetlands of southern Chile. Studies on Neotropical Fauna and Environment 37: 9-14.

Escaida, J., Jaramillo, E., Amtmann, C., Lagos, N.A. 2015. Crisis socioambiental: el humedal del Río Cruces y el cisne de cuello negro. Ediciones Universidad Austral de Chile. 264 pp.

Fariña, J., Camaño, A. 2012. Humedales Costeros de Chile. Aportes Científicos a su Gestión Sustentable. Ediciones Universidad Católica de Chile. 437 pp.

Fariña, J., He, Q., Silliman, B., Bertness, M. 2018. Biogeography of salt marsh plant zonation on the pacific coast of South America. Journal of Biogeography 45:238-247.

Fariña, J., He, Q., Silliman, B., Bertness, M. 2016. Bottom- up and top- down human impacts interact to affect a protected coastal Chilean marsh. Ecological Society of America 97(3), pp. 640-648.

González, P., Ortiz, S., Jerez, R., PÁvez, M., Arcos, D. 2017. Effects of the 2010 tsunami on the Mataquito river wetland. In: The ecology and natural history of Chilean saltmarshes. Fariña, J.M., Camaño, A. (eds.) Springer, 348 pp. ISBN 978-3-319-63877-5; DOI: 10.1007/978-3-319-63877-5_9.

Jaramillo, E., Lagos, N.A., Labra, F.A., Paredes, E., Acuña, E., Melnick, D., Manzano, M., Velásquez, C., Duarte, C. 2018a. Recovery of black-necked swans, macrophytes and water quality in a Ramsar wetland of southern Chile: assessing resilience following sudden anthropogenic disturbances. Science of the Total Environment 628-629: 291-301.

Jaramillo, E., Duarte, C., Labra, F.A., Lagos, N.A., Peruzzo, B., Silva, R., Velasquez, C., Manzano, M., Melnick, D. 2018b. Resilience of an aquatic macrophyte to an anthropogenically induced environmental stressor in a Ramsar wetland of southern Chile. Ambio https://doi. org/10.1007/s13280-018-1071-6.

Lagos, N.A., Paolini, E., Jaramillo, E., Lovengreen, C., Contreras, H., Duarte, C. 2008. Environmental processes, water quality and decline of waterbird populations in the Rio Cruces Ramsar wetland. Wetlands 28(4): 938-950.

Madariaga, R. 1998. Sismicidad de Chile. Física de la Tierra 10: 221-58.

Marín, A., Gelcich, S., Castilla, J. 2014. Ecosystem services and abrupt transformations in a coastal wetland socialecological system: Tubul-Raqui after the 2010 earthquake in Chile. Ecology and Society 19(1): 22. 
Martínez, C., Contreras-López, M., Winckler, P., Hidalgo, H., Godoy, E., Agredano, R. 2017. Coastal erosion in central Chile: a new hazard?. Ocean and Coastal Management XXX: $1-15$.

National Geophysical Data Center / World Data Service (NGDC/WDS). 2018. Global historical tsunami database. National Geophysical Data Center, NOAA. doi:10.7289/ V5PN93H7 (Accessed: January 28, 2018).

Norambuena, C., Bozinovic, F. 2009. Health and nutritional status of a perturbed Black necked swan (Cygnus melanocoryphus) population: diet quality. Journal of Zoo and Wildlife Medicine 40 (4): 607-616.

Plafker, G., Savage, J.C. 1970. Mechanism of the Chilean earthquakes of May 21 and 22, 1960. Geological Society of America Bulletin 81: 1001-1030.

Ruiz, S., Moreno, M., Melnick, D., Campo, F., Poli, P., Baez, J.C., Leyton, F., Madariaga, R. 2017. Reawakening of large earthquakes in South-Central Chile: The 2016 Mw7. 6 Chiloé event. Geophysical Research Letters 44:66336640 .
Schlatter, R. 1998. El cisne de cuello negro (Cygnus melanocoryphus) en Chile. In: Valverde, V. (ed.). La Conservación de la Fauna Nativa de Chile, Logros y Perspectivas. CONAF, Ministerio de Agricultura, Chile: 121-131.

Schlatter, R.P., Navarro, R.O., Corti, P. 2002. Effects of El Niño Southern Oscillation on numbers of Black-necked swans at río Cruces Sanctuary, Chile. Colon. Waterbirds 25 (Spec. Pub. 1): 114-122.

UACH. 2015. Programa de Diagnóstico Ambiental del Humedal del Río Cruces y sus Ríos Tributarios. Universidad Austral de Chile. 1508 pp.

UACH. 2017. Programa de Monitoreo Ambiental Actualizado del Humedal del Río Cruces y sus Ríos Tributarios. Universidad Austral de Chile. 830 pp.

Valdovinos, C., Sandoval, N., VÁsquez, D., Olmos, V. 2012. El Humedal Costero Tubul- Raqui: Un ecosistema chileno de alto valor de conservación severamente perturbado por el terremoto del 2010. En: Fariña, M.J., Camaño, A., (eds) Humedales Costeros de Chile. Aportes Científicos a su Gestión Sustentable. Ediciones Universidad Católica de Chile. 391-437.

Recibido: 02.10.2018

Aceptado: 15.11.2018 